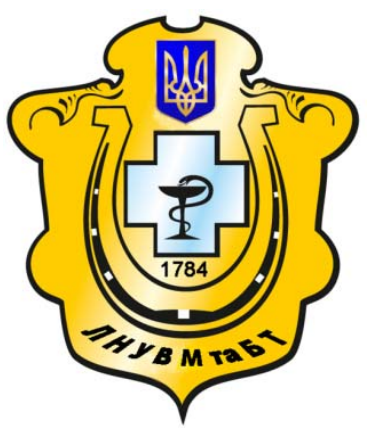

Науковий вісник Львівського національного університету ветеринарної медицини та біотехнологій імені С.3. Гжицького

Scientific Messenger of Lviv National University of Veterinary Medicine and Biotechnologies named after S.Z. Gzhytskyj

doi:10.15421/nvlvet6832

ISSN 2413-5550 print

ISSN 2518-1327 online

$\underline{\text { http://nvlvet.com.ua/ }}$

УДК 637.14/.34

\title{
Розроблення технології ферментованих напоїв на основі сироватки
}

\author{
Н.Б. Сливка, О.Р. Михайлицька, І.М., Турчин \\ slyvkanat@ukr.net,ola75@ukr.net, turchyn@ukr.net
}

Львівський національний університет ветеринарної медицини та біотехнологій імені С.3. Гжиџького, вул. Пекарська, 50, м. Львів, 79010, Україна

\begin{abstract}
Метою досліджень було розробити технологію ферментованих сироваткових напоїв із екстрактом меліси. Зразки меліси лимонної було зібрано протягом червня-серпня у смт. Красне Львівської області, висушено за температури $40{ }^{\circ} \mathrm{C}$. Співвідношення сухої меліси та екстрагенту (очищеної води) 1:1. Тривалість процесу екстрагування складає 60 хв. при температурі $60{ }^{\circ} \mathrm{C}$. Для приготування сироваткових напоїв використовували нативну молочну сироватку, отриману з-під сиру кисломолочного з масовою часткою сухих речовин $5,5 \%$, кислотністю $70^{\circ} \mathrm{T}$, та освітлену молочну сироватку, отриману за допомогою теплової денатурації за температури $90-95{ }^{\circ} \mathrm{C}$ з наступним відділенням білків. Сироваткові напоі виготовляли резервуарним способом. Для заквашування використовували закваску Kefir12 компанії Chr.Hansen. Для покращення кольору використовували натуральний барвник «Карамель», кількість якого у дослідних зразках становила від 0,5 до

Встановлено оптимальні дози рецептурних компонентів, зокрема сироватки освітленої, иукру, екстракту меліси, барвника «Карамель», регулятора кислотності та заквашувального препарату.
\end{abstract} $1,5 \mathrm{k} 2 / \mathrm{m}$.

Ключові слова: сироватка, екстракт, меліса лимонна, технологія, органолептичні показники, барвник.

\section{Разработка технологии ферментированных напитков на основе сыворотки}

\author{
Н.Б. Сливка, О.Р. Михайлицкая, И.М. Турчин \\ slyvkanat@ukr.net,ola75@ukr.net, turchyn@ukr.net
}

Львовский национальный университет ветеринарной медицины и биотехнологий имени С.3. Гжицкого, ул. Пекарская, 50, г. Львов, 79010, Украина

Целью исследований было разработать технологию ферментированных сывороточных напитков с экстрактом мелисcы. Образиы мелиссы лимонной были собраны в течение июня-августа в пгт. Красне Львовской области, высушено при температуре $40^{\circ} \mathrm{C}$. Соотношение сухой мелиссы и экстрагента (очищенной воды) 1:1. Продолжительность процесса извлечения составляет 60 мин. при температуре $60^{\circ} \mathrm{C}$. Для приготовления сывороточных напитков использовали нативную молочную сыворотку, полученную из-под творога, с массовой долей сухих веществ 5,5\%, кислотностью $70^{\circ} \mathrm{T} и$ осветленную молочную сыворотку, полученную с помощью тепловой денатурации при температуре $90-95{ }^{\circ} \mathrm{C} \mathrm{c}$ последующим отделением белков. Сывороточные напитки изготавливали резервуарным способом. Для сквашивания использовали закваску Kefir12 компании Chr.Напsеп. Для улучшения ивета использовали натуральный краситель «Карамель», количество которого в опытных образиах составляло от 0,5 до 1,5 кг/m.

Установлены оптимальные дозы рецептурных компонентов, в частности сыворотки осветленной, сахара, экстракта мелиссы, красителя «Карамель», регулятора кислотности и заквасочного препарата.

Ключевые слова: сыворотка, экстракт, мелисса лимонная, технология, органолептические показатели, краситель.

Citation:

Slyvka, N., Myhaylytska, O., Turchyn, I. (2016). Development of technology of fermented drinks based on whey. Scientific Messenger LNUVMBT named after S.Z. Gzhytskyj, 18, 2(68), 153-156. 


\title{
Development of technology of fermented drinks based on whey
}

\author{
N. Slyvka, O. Myhaylytska, I. Turchyn \\ slyvkanat@ukr.net,ola75@ukr.net, turchyn@ukr.net \\ Lviv National University of Veterinary Medicine and Biotechnologies named after S.Z. Gzhytskyi, \\ Pekarska Str., 50, Lviv, 79010, Ukraine
}

\begin{abstract}
The aim of research was to develop technology fermented whey drink with Melissa extract. The samples of Lemon Melissa were collected during June-August in the village Krasne in Lviv region, dried at $40{ }^{\circ} \mathrm{C}$. Ratio of dry Melissa and extractant (purified water) was 1: 1. The duration of the extraction process is 60 minutes at $60^{\circ} \mathrm{C}$. To prepare the whey drinks used native whey obtained from the cottage cheese with a mass fraction of solids $5.5 \%$ acidity $70^{\circ} \mathrm{T}$ and lit whey obtained by using the thermal denaturation at a temperature of $90-95^{\circ} \mathrm{C}$ with subsequent separation of proteins. For fermentation used starter Kefir 12 of company Chr. Hansen. For improvement of color used natural coloring agent «Caramel», the quantity of that in the experimental samples ranged from 0.5 to $1.5 \mathrm{~kg} / \mathrm{t}$. Whey drinks were produced reservoir manner.

Whey make lighten at temperature $92-94{ }^{\circ} \mathrm{C}$ with an exposure of $15-20$ seconds. The whey subjected filtering for remove the sediment. Then whey is cooled to a temperature of fermentation, add Melissa extract and direct-vat-starter and fermented at temperature $30-45^{\circ} \mathrm{C}$ during $6-8$ hours to achieve an acidity in the range $120-200^{\circ} \mathrm{T}$. After fermentation sugar and natural colorant added to whey, stirred and cooled to a temperature of $2-8{ }^{\circ} \mathrm{C}$. Then send the finished product to bottling. Then finished product send for bottling.

Determined the optimal dose of prescription components, including the whey lighted, sugar, Melissa extract, dye «Caramel», acidity regulator and ferment preparation.

Were conducted organoleptic assessment whey drinks, defined the main physical and chemical properties. It was determined by research that the acidity of drinks based on native whey was lower and amounted $127^{\circ} \mathrm{T}$ against $142^{\circ} \mathrm{T}$ in drinks with lighted whey. Also, the presence of whey protein in drinks has provided turbidity that worsened its organoleptic properties. The viscosity of the product increased with increasing amounts Melissa extract, which is associated with an increase of dry matter in the product and starters composition, which contains of Streptococcus thermophilus. Has increased ability to retain moisture, which compared to control larger on $2.2-3.9 \%$.
\end{abstract}

Key words: whey, extract, lemon Melisa, technology, organoleptic indexes, dyes.

\section{Вступ}

У третьому тисячолітті охорона довкілля стає першочерговим питанням, яке привертає особливу увагу спільноти. Недостатнє промислове використання відходів зумовлює великі втрати цінних речовин, зниження ефективності виробництва та необхідність сплати штрафів за скидання викидів.

Під час виробництва сирів утворюється велика кількість сироватки - близько 85\% від об єму молока, яке переробляють. Основну частину сироватки разом iз стічною водою скидають до каналізації, що створює екологічну проблему. Серед загального обсягу стічних вод вітчизняних молокопереробних підприємств $60 \%$ займає сироватка. Основними причинами є недотримання нормативів збору; конструкції обладнання, в яких відсутнє пристосування для збору сироватки або відсутність технічної бази для їі переробки; несвідоме ставлення керівників підприємств та держави до втрати цінних сировинних ресурсів (Kaprelyants and Iorhachova, 2003; Domaretskyy et al., 2005; Bilyk and Dronyk, 2009).

Одним із найпростіших способів переробки молочної сироватки 3 технологічної точки зору є іiї використання для виробництва напоїв як свіжих, так і ферментованих. Молочна сироватка має профілактичні та лікувальні властивості завдяки вуглеводному і вітамінному комплексам. За якісним складом та кількістю макро- і мікроелементів напої зі сироватки значно перевершують традиційні освіжаючі напої, серед них і мінеральні води. Також сироватка містить всі незамінні амінокислоти.
Ферментовані напої на основі сироватки містять цінні компоненти як сировини, так і продукти метаболізму мікроорганізмів, що утворюються при бродінні (етиловий спирт, леткі кислоти, ферменти, ароматичні сполуки та ін.).

Широкої популярності набувають сироваткові напої із використанням рослинної сировини, зокрема в комбінації з різними фруктами, ягодами та соками. Це стало модною тенденцією в здоровому харчуванні. Перевагою такої продукції є низька вартість, що робить їх доступними для пересічного споживача.

Лікарські рослини поки що не є традиційною сировиною для виробництва харчових продуктів, проте спектр їх застосування в харчовій промисловості стрімко зростає.

На наш погляд, прекрасною сировиною для виготовлення сироваткових напоїв $\epsilon$ меліса лимонна, яка поширена у західних областях України. Корисні властивості листя меліси були відомі ще в стародавні часи. Авіценна використовував цю рослину для зміцнення організму. Вона містить велику кількість органічних кислот, сапоніни, флавоноїди, смоли, таніни, дубильні речовини, ефірні масла. Продовжити цей список можна такими мікроелементами як Купрум, Манган, Ферум, Калій, Селен, Цинк, Магній, Кальцій, а також вітамінами групи В і С. Наземна частина (в основному листки) містить 0,30-0,35\% ефірної олії, 0,45\% аскорбінової кислоти, смоли, близько 5\% дубильних речовин тощо. Основні компоненти ефірної олії - цитраль (60\%), цитронелал, гераніол, лінолоол. Ефірна олія має сильний запах. У 100 г трави меліси лимонної міститься лише 44 ккал. 
Метою нашої роботи було розробити технологію сироваткових ферментованих напоїв із рослинною сировиною та дослідити їх властивості.

\section{Матеріал та методи досліджень}

Зразки меліси лимонної було зібрано протягом червня-серпня у смт. Красне Львівської області, висушено за температури $40^{\circ} \mathrm{C}$.

Для одержання екстрактів сировину подрібнювали до розміру часток 3 мм для збільшення поверхні частинок сировини і контакту твердої та рідкої фази при екстрагуванні. Як екстрагенти використовували очищену воду і підсирну сироватку. Співвідношення сухої меліси та екстрагенту 1:1. Екстрагували при періодичному струшуванні до досягнення максимального вмісту сухих речовин у екстракті.

Матеріалом для досліджень стали водний та сироватковий екстракт.

Для приготування сироваткових напоїв використовували такі види молочної сироватки:

- нативну молочну сироватку, отриману з-під сиру кисломолочного $з$ масовою часткою сухих речовин $5,5 \%$, кислотністю $70^{\circ} \mathrm{T}$;

- освітлену молочну сироватку, отриману за допомогою теплової денатурації за температури $90-95^{\circ} \mathrm{C} 3$ наступним відділенням білків.

Для заквашування використовували закваску Kefir12 компанії Chr.Hansen, до складу якої входять мезофільні та термофільні мікроорганізми, а також молочні дріжджі. Для збільшення густоти продукту в закваску в комбінації з мезофільними мікроорганізмами введений структуроутворювач Streptococcus thermophilus.

Для покращення кольору використовували натуральний барвник «Карамель» компанії Chr.Hansen, який отримують шляхом контрольованого нагрівання харчових вуглеводів. Кількість барвника у дослідних зразках становила від 0,5 до 1,5 кг/т.

\section{Результати та їх обговорення}

Найзручнішими для використання в технології ферментованих молочних напоїв вважаються екстракти - витяги з рослинної сировини.

Оптимальна тривалість процесу екстрагування водою складає 60 хв. при температурі $60{ }^{\circ} \mathrm{C}$, підсирною сироваткою - 90 хв. при цій же температурі.

При виробництві молочних продуктів важливим $\epsilon$ ï органолептичні показники. Тому слід дослідити органолептичні характеристики отриманих екстрактів. У табл. 1 представлено характеристику зовнішнього вигляду, запаху та смаку водного та сироваткового екстрактів.

Таблиия 1

Органолептичні показники екстрактів з листя меліси

\begin{tabular}{|c|c|c|c|}
\hline Вид екстракт & Зовнішні й вигляд & Запах & Смак \\
\hline Водний & світло-оранжевий & $\begin{array}{c}\text { слабкий, приємний трав'яний } 3 \\
\text { нотами лимону }\end{array}$ & $\begin{array}{c}\text { слабковиражений, пряний } 3 \\
\text { кислинкою }\end{array}$ \\
\hline Сироватковий & $\begin{array}{c}\text { каламутний розчин світло- } \\
\text { оранжевого кольору }\end{array}$ & $\begin{array}{c}\text { своєрідний трав'яний з ледь } \\
\text { відчутними відтінками кислоти }\end{array}$ & кислуватий, трохи терпкий \\
\hline
\end{tabular}

3 табл. 4.3. видно, що кращими характеристиками володіє водний екстракт, тому пропонуємо його залучити до рецептури молочних напоїв.

Екстракти після одержання зберігали за температури $+4{ }^{\circ} \mathrm{C}$, досліджуючи динаміку змін органолептичних та мікробіологічних показників протягом 7 діб після їх одержання. Перші ознаки псування водних та сироваткових екстрактів з'явилися на п'яту добу.

Ферментовані сироваткові напої виготовляли резервуарним способом. Сировиною була нативна та освітлена сироватки. Сироватку освітлюють при температурі $92-94{ }^{\circ} \mathrm{C}$ з витримкою 15-20 секунд. Для видалення осаду піддають фільтруванню. Потім сироватку охолоджують до температури заквашування, додають екстракт меліси та закваску прямого внесення і сквашують при температурі $30-45^{\circ} \mathrm{C}$ протягом 68 годин до досягнення кислотності в межах 120 $200^{\circ} \mathrm{T}$. По закінченні сквашування до сироватки додають цукор та барвник натуральний, перемішують охолоджують до температури $2-8{ }^{\circ} \mathrm{C}$. Далі готовий продукт відправляють на розлив.

Під час ферментації з різними видами молочної сироватки контролювали титровану кислотність та органолептичні показники. Слід зазначити, що кислотність напоїв на основі нативної сироватки була ниж- чою і становила $127^{\circ} \mathrm{T}$ проти $142^{\circ} \mathrm{T}$ у напоях із освітленої сироватки. Також присутність сироваткових білків надавала напоям мутність. Позитивним при використанні освітленої сироватки для ферментованих напоїв $\epsilon$ те, що при видаленні азотистих сполук суттєво послаблюється незвичний для споживача специфічний присмак сироватки. Основними причинами утворення останнього $\epsilon$ реакції за участі білків (розчеплення, дія світла і кисню, реакції між білками та вуглеводами).

Тому до рецептури ми внесли освітлену сироватку.

Були зроблені експерименти із введенням у молочну основу різної кількості барвника та екстракту меліси 3 метою пошуку подальших оптимальних показників. Під час проведення досліджень визначали органолептичні показники. Слід зазначити, що змін зазнавав лише колір продукту. При внесенні $0,5 \%$ колір молочного напою був солом'яно-жовтий, приємний, при внесенні $1 \%$ - світло-коричневий, а при $1,5 \%$ - насичений коричневий. В результаті органолептичних досліджень обрано оптимальну кількість барвника, яка становить $0,5 \%$.

Сформовані рецептури (табл. 2) напоїв на основі сироватки із додаванням цукрового колеру та екстракту меліси. 
Рецептури ферментованих сироваткових напоїв

\begin{tabular}{|c|c|c|c|c|}
\hline \multirow{2}{*}{ Компоненти } & \multicolumn{3}{|c|}{ Маса компонентів } \\
\cline { 2 - 5 } & Контроль & Дослід 1 & Дослід 2 & 909,5 \\
\hline Сироватка підсирна & 950,0 & 919,0 & 50.0 & 300,0 \\
\hline Цукор & 50,0 & 50,0 & 50.0 & 4,0 \\
\hline Екстракт меліси & - & 27,0 & 1,0 & 2,5 \\
\hline Барвник карамель & - & 2,5 & 1,5 & 1000 \\
\hline Регулятор кислотності & - & 1000 & 1000 & \\
\hline
\end{tabular}

\begin{tabular}{|c|c|c|c|c|}
\hline \multirow{2}{*}{$\begin{array}{c}\text { Найменування } \\
\text { показника }\end{array}$} & \multirow{2}{*}{ Контроль } & \multicolumn{3}{|c|}{ Варіанти } \\
\hline & & 1 & 2 & 3 \\
\hline $\begin{array}{c}\text { Титрована } \\
\text { кислотність, }{ }^{\circ} \mathrm{T}\end{array}$ & 120 & $74 \pm 1$ & $70 \pm 1$ & $69 \pm 1$ \\
\hline $\begin{array}{c}\text { Активна кислотність, } \\
\text { од. } \mathrm{pH}\end{array}$ & 4,6 & 4,5 & 4,5 & 4,5 \\
\hline $\begin{array}{c}\text { В'язкість } 100 \mathrm{~cm}^{3} \\
\text { Згустку, с }\end{array}$ & 94,5 & 99,5 & 110,5 & 111,8 \\
\hline Синерезис, \% & 18,0 & 15,0 & 12,0 & 11,0 \\
\hline $\begin{array}{c}\text { Вологоутримувальна здатність, } \\
\%\end{array}$ & 92,3 & 94,5 & 95,4 & 96,2 \\
\hline
\end{tabular}

Дослідження фізико-хімічних показників наведено у табл. 3.

Як видно $з$ табл. 3 в'язкість продукту збільшується i3 збільшенням кількості екстракту меліси, що пов'язано із збільшення сухих речовин у продукті. Збільшення в'язкості можна пояснити також і складом закваски, до складу якої належать Streptococcus thermophilus. Це веде до підвищення вологоутримувальної здатності. Порівняно з контролем вона більша на $2,2-3,9 \%$.

\section{Висновки}

Розроблено рецептури ферментованих сироваткових напоїв та досліджено органолептичні та фізико- хімічні властивості готових продуктів. Розроблено технологічну схему для їх виробництва.

\section{Бібліографічні посилання}

Bilyk, O.Y., Dronyk, H.V. (2009). Molochna syrovatka tsinna syrovyna dlya vyrobnytstva funktsionalnykh produktiv. Naukovyy visnyk LNUVMBT imeni S.Z. Hzhytskoho. 11, 2(41), 422a-422 (in Ukrainian).

Domaretskyy, V.A., Prybylskyy, V.L., Mykhaylov, M.H. (2005). Tekhnolohiya ekstraktiv, kontsentrativ i napoyiv iz roslyn- noyi syrovyn: pidruch. Vinnytsya: Nova knyha (in Ukrainian).

Kaprelyants, L.V., Iorhachova, K.H. (2003). Funktsionalni produkty. Odesa: Druk (in Ukrainian). Стаття надійшла до редакиії 4.10.2016 